Primljen / Received: 22.2.2016. Ispravljen / Corrected: 4.8.2016.

Prihvaćen / Accepted: 2.2.2017.

Dostupno online / Available online: 10.4.2017.

\section{Influence of recycled filler on asphalt mix properties}

Authors:

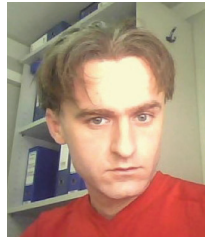

Ivica Androjić, PhD. CE

University of Rijeka

Faculty of Civil Engineering

ivica.androjic@gmail.com

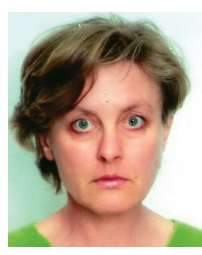

Gordana Kaluder, MCE

GFK Consulting, Belišće, Vroatia

gfkconsulting@net.hr

\section{Ivica Androjić, Gordana Kaluder}

\section{Influence of recycled filler on asphalt mix properties}

An overview of research conducted so far on the use of various recycled materials as replacement for stone filler in asphalt mixes is presented in the paper. The paper comprises an overview of research on the influence exerted by the waste glass, waste materials from cement industry, concrete, brick, ceramics, fly ash and other materials, on physicomechanical properties of bitumen mixes. As a final result, conclusions are given on the possible use of individual recycled materials as replacements for standard rock flour in asphalt mixes.

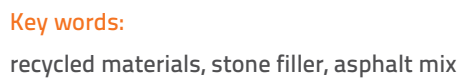

Pregledni rad

Ivica Androjić, Gordana Kaluder

Utjecaj recikliranog punila na svojstva asfaltnih mješavina

U radu se daje prikaz provedenih dosadašnjih istraživanja s primjenom različitih recikliranih materijala koji se koriste kao zamjena za kameno punilo u asfaltnim mješavinama. Rad obuhvaća prikaz provedenih istraživanja o utjecaju otpadnog stakla, otpada cementne industrije, betona, opeke, keramike, letećeg pepela i drugih na fizikalno mehanička svojstva bitumenskih mješavina. Kao konačan rezultat donose se zaključci o mogućoj primjeni pojedinih recikliranih materijala kao zamjeni za standardno kameno brašno u asfaltnim mješavinama.

Ključne riječi:

reciklirani materijali, kameno punilo, asfaltna mješavina

Übersichtsarbeit

Ivica Androjić, Gordana Kaluder

Einfluss recycelten Füllmaterials auf die Eigenschaften von Asphaltmischungen

In dieser Arbeit werden bisher durchgeführte Untersuchungen zur Anwendung verschiedener recycelter Materiale, die als Ersatz für Gesteinskörnungen in Asphaltmischungen verwendet werden, dargestellt. Die Arbeit umfasst eine Übersicht der Untersuchungen zum Einfluss von Abfallglas, Abfällen der Zementindustrie, Abfällen aus Beton, Mauerwerk, Keramik, Flugasche und anderen Materialen auf physikalischmechanische Eigenschaften von Bitumenmischungen. Als Resultat werden Schlussfolgerungen zur möglichen Anwendung einzelner recycelter Materiale als Ersatz für herkömmliches Gesteinsmehl in Asphaltmischungen gegeben.

Schlüsselwörter:

recyceltes Material, Gesteinskörnung, Asphaltmischung 


\section{Introduction}

The use of alternative materials in road construction is highly significant because of great demand for such materials in this industry. According to Barišić et al. [1], alternative materials are all materials obtained as construction waste and other types of industrial waste. Based on the instruction given in the directive 2008/98/EC, minimum $50 \%$ of household waste, and $70 \%$ of construction and industrial waste, must be recycled and reused by 2020 [2].

Asphalt mixes contain mineral mixture, filler, binder, and various additives that are added to the mixture at a specified temperature. An average annual production of asphalt mixes amounted to 302.51 million tons in Europe in the period from 2008 to 2014 , which is by 38.35 million tons less compared to the corresponding production in the USA [3]. Thus, the proportion of available quantity of recycled mixture amounted to $38,997.41$ million tons in the EU countries in 2014, which is by 29,702.59 million tons less compared to the USA. In the same year, the available quantity of recycled asphalt mixture amounted to 170,000 tons in Croatia [3]. Many studies about the use of various alternative materials in asphalt mixtures have been undertaken. Thus, McDonald [4] considers in his paper possible use of plastics, incinerator ash, waste tyres, shingles, fly ash, slag, cement dust, recycled asphalt, glass, etc., in asphalt mixtures. In this respect, some authors [5-9] study possible use of recycled asphalt in the production of new asphalt mixtures, in the production of waste plastics [10-13], in the production of waste glass [14-15], and in the production of fly ash [16-17] etc. The use of alternative materials in the production of asphalt mixtures generally leads to economic savings and smaller negative environmental effects, while also being compliant with relevant quality requirements. Fillers added to asphalt mixtures are used for filling the voids, for meeting grading requirements, for increasing stability, and for improving the bond between bitumen and aggregate [18]. This group includes mineral dust created by crushing and sieving aggregate (including the return filler), cement, lime, etc. Filler influences behaviour of bitumen binder and mixtures, i.e. an increase in its content results in the stiffening or hardening of asphalt mixture. According to some specifications, the weight proportion of dust and bitumen binder in asphalt mixtures should range from 0.6 to 1.2 [18]. In asphalt mixes, the following substances can be used as filler: stone dust, lime, Portland cement, fly ash, waste glass, waste from cement industry, waste concrete, brick, ceramics, fly ash, etc. In the Detailed Elaboration of Technical Properties and Requirements for Construction Products Used in the Production of Asphalt Mixes and Asphalt Pavements [19], filler is defined as aggregate with dominant particle size of less than $0.063 \mathrm{~mm}$, and with all particles passing through the $2 \mathrm{~mm}$ sieve. It is allowed to use mineral filler (lime or dolomite filler), mixed filler (mixture of mineral filler and calcium hydroxide), hydrated lime, cement and fly ash generated by coal combustion. It is also specified that the use of return filler is not allowed for asphalt mixtures SMA, BBTM and PA.
The objective of this research is to provide an overview of possible use of various recycled materials serving as replacement for standard filler in asphalt mixtures. The analysis of individual replacement of standard filler in asphalt mixes with recycled materials is considered because of considerable influence fillers have of physicomechanical properties of standard bituminous mixtures. The final objective of the research is to point to possible advantages and shortcomings of the use of individual replacement waste materials.

\section{Overview of current situation}

Filler is an integral component of asphalt mixtures and its content greatly affects mechanical properties of such mixtures. If the filler content is too high the bituminous mixture can be weakened considerably as in this case the filler influences an optimum content of bitumen and placeability, while also changing highly elastic properties of bituminous mortar. Proportions of asphalt sample components are presented in Figure 1.

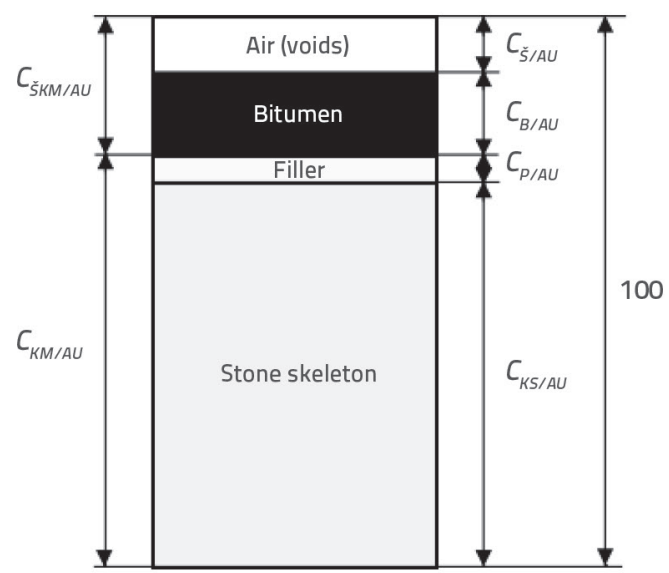

Figure 1. Asphalt sample model [20]

It can be seen from Figure 1 that asphalt sample is composed of the stone skeleton, filler, bitumen, and air voids. The filler quality is greatly influenced by its grading. According to SantosBurdini et al. [21], the minimum percentage of mineral filler passing through the $0.075 \mathrm{~mm}$ sieve amounts to $65 \%$. The Detailed Elaboration [19] inter alia specifies that the minimum percentage of filler passing through the $0.063 \mathrm{~mm}$ sieve must be $70 \%$ and, at that, $100 \%$ of filler must pass through the $2 \mathrm{~mm}$ sieve.

\subsection{Use of waste glass}

Glass is the only material that can be fully recycled several times [22]. It is obtained by melting quartz sand, soda and limestone and, at that, glass fragments are also used. In 2011, the proportion of glass waste production in EU-27 countries amounted to $32 \mathrm{~kg}$ per inhabitant [23]. In some EU countries the proportion of recycling has reached as much as $60 \%$, which 
is much more compared to situation in the Republic of Croatia where 33,747 tons of waste glass was collected and classified in 2012 [24]. Hand-crushed waste glass used as replacement for a part of filler in the testing is shown in Figure 2 [25].

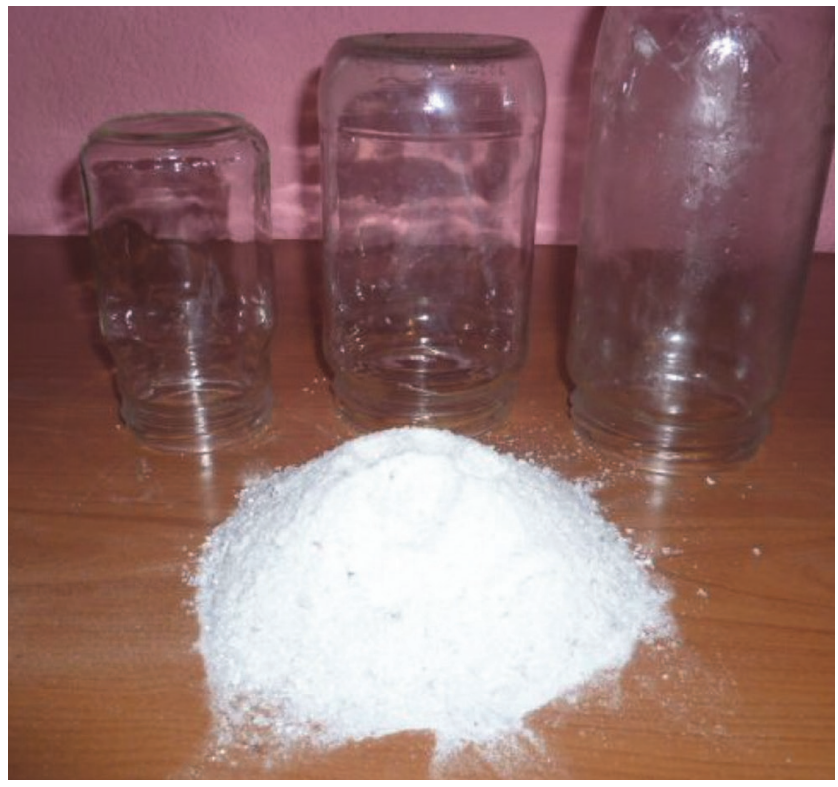

Figure 2. Waste glass as partial replacement of stone dust [25]

In the study conducted by Hassan et al. [26], glass powder is used as an alternative for mineral filler (stone dust) in the hot asphalt mixture. The total of nine mixes with three types of filler were tested (three are lime and stone dust, three are Portland cement, and three are glass powder). Three mixtures, in which the glass powder content amounted to 4, 7 and $10 \%$ of the total aggregate weight, were tested. The authors have concluded that an optimum proportion of glass powder is the one replacing seven percent of the total aggregate weight. Here the thirteen percent greater stability was obtained compared to the remaining six mixes, the deformation was reduced by $39 \%$, and the asphalt mix density was reduced by $10 \%$.

In their paper, Jony et al. [27] analyse the influence of the use of various fillers, including glass powder. The authors propose the use of glass powder as this contributes to an increase in the Marshall's stability compared to fillers made of Portland cement and lime.

in their research, Shaopeng et al. [28] state that glass powder can be used as replacement for mineral filler and aggregate up to the grain size of $4.75 \mathrm{~mm}$ The maximum content with respect to the total aggregate weight is $10 \%$.

Pereira et al. [29] analyse the effect of waste glass when used as filler replacement in asphalt mixture. The authors conclude that there is no great difference with regard to effect realised using stone dust, i.e. Marshall test values are almost similar. The same authors conclude that this waste material is acceptable for use in asphalt mixtures.

\subsection{Waste from cement industry}

Cement is a complex binding composite material whose annual worldwide production approximates 3 billion tons and, due to its typical properties, it has a considerable impact on environment [30]. It is produced by pulverisation and baking of limestone and marl until a fine powder is obtained. In cement industry, there are many sources of dust emission during production process. Dust can originate from kilns, clinker coolers, raw material mills, etc.

In their paper, Hassan et al. ([31] analyse the possibility of replacing filler with waste cement dust in the proportion of $0,25,50,75$ and $100 \%$ by weight. The testing comprised determination of mechanical properties by Marshall test, and indirect tensile strength and compressive strength testing. The results show that the stability increases and deformation decreases with an increase in waste cement dust content. An optimum proportion of waste cement that replaces stone dust is $100 \%$, i.e. the stone dust is fully replaced by cement.

Khaled and Ahmed [32] studied the possibility of using waste white cement dust from cement industry as a replacement for filler in asphalt mixtures. Five samples were subjected to Marshall testing. In these samples the proportion of stone dust was replaced with 2, 4, 6 and 8 percent of white cement dust. An optimum proportion of bitumen in the control mixture amounted to 5.5 percent. The results show that the $2 \%$ dust substitution for stone dust gives the optimum bitumen proportion that is almost similar to the control mixture. The four percent dust substitution slightly increases an optimum proportion of bitumen to 5.7 percent without a significant negative effect on asphalt mixture (stability, voids, etc.). However, further increase in dust content ( 6 and $8 \%$ ) increases an optimum bitumen content to 6.1 and $6.2 \%$, which influences cost-efficiency of this use. The authors have concluded that $4 \%$ of dust is an optimum replacement for stone dust.

In their research, Taha et al. [33] use three different asphalt mixtures, one of them being the control mixture (with stone dust as filler) and, in the remaining two, the cement dust is replaced with 5 and $13 \%$ of filler, respectively. The mixture with $5 \%$ of cement dust had the optimum content of binder similar to the one registered for the control mixture, while the mixture with 13 $\%$ of cement dust required much greater content of binder and is therefore considered economically inefficient.

\subsection{Waste concrete, brick and ceramics}

Construction waste is generated during construction of buildings and other facilities, and during renovation, renewal and maintenance of such buildings and facilities. This waste group includes concrete, bricks, tiles and other materials.

In their paper, Sutradhar et al. [34] conclude that waste concrete and brick particles of up to $0.075 \mathrm{~mm}$ in size can be considered acceptable as replacement for filler. The asphalt mixture in which the recycled concrete and recycled brick powder is used 
as replacement for filler exhibits practically the same properties according to Marshall as the mixtures with the traditional filler (stone dust). The stability of a mixture increases with an increase in bitumen content. The maxiumum stability of 11.18 kN with $5.5 \%$ of bitumen was obtained by bitumen mixes with the recycled brick dust as filler. The mixtures in which the recycled concrete dust was used as filler exhibited high stability ( $11 \mathrm{kN}$ at $5.5 \%$ of bitumen), while mixtures with stone dust as filler exhibited lower stability of $9.68 \mathrm{kN}$ at the same proportion of bitumen.

In their paper, Taherkani i Golzari [35] analyse the possibility of using recycled concrete powder and steelworks slag as replacement for stone dust in asphalt mixtures. The control mixture contains $100 \%$ of stone dust. Instead of stone dust, other mixes contain 25,50, 75 and $100 \%$ of recycled concrete dust and/or steelworks slag (four mixtures with concrete and four mixtures with steelworks slag). This study proves that the stability of mixtures with concrete and slug, measured according to Marshall, exceeds the stability of control mixture. It can also be concluded that the deformation of mixture with concrete is greater compared to the control mixture, but the deformation of mixture with slag is smaller than that of the control mixture. The greatest Marshall stiffness of mixtures (concrete, slag) is obtained at the 25 and $75 \%$ replacement of stone dust by weight. The results show that the stone dust replacement with these waste materials does not influence volumetric properties of the mixture. Indirect tensile strength values of mixtures (concrete, slag) in which the proportion of these materials in filler amounts to $25 \%$ and $50 \%$, respectively, are greater compared to those registered at the control mixture. In addition, the water resistance and stiffness of mixtures with waste materials is higher compared to similar values for the control mixture.

Chen et al. [36] conducted X-ray testing in laboratory conditions. They analysed the possibility of using recycled concrete dust by means of scanning electron microscopy and $x$-ray fluorescence spectroscopy. It was established that the waste concrete dust is mainly composed of quartz $\left(\mathrm{SiO}_{2}\right)$ and calcite $\left(\mathrm{CaCO}_{3}\right)$, i.e. that the Si content is higher compared to the traditional stone dust, while the Ca content is lower. They also established that this material can improve the mixture's resistance to water temperature and fatigue. The authors also concluded that this material, when used as filer, can reduce temperature of the asphalt mixture, and can be appropriate as material for geographic areas characterised by high temperatures.

\subsection{Fly ash and other materials}

The use of fly ash and other recycled materials as replacement for traditional filler is presented in the following text. Asphalt samples with fly ash [37] are presented in Figure 3.

In their paper, Muniandy and Aburkaba [38] tested the SMA mixture (Stone Mastic Asphalt Mixture) in which the following materials were used as filler: stone dust, ceramic dust, fly ash from coal, and steelworks slag. The influence of the type of waste material and particle size of filler on the indirect tensile stiffness and fatigue properties of material was tested. The proportion of filer in asphalt mix amounted to $10 \% \mathrm{~m} / \mathrm{m}$, the maximum particle size for all filler types was $0.075 \mathrm{~mm}$, and the filler always contained only one type of material. For all types of waste material, the following proportion combinations were used: $100 \%$ of particles up to $0.075 \mathrm{~mm}$ in size, $100 \%$ of particles up to $0.02 \mathrm{~mm}$ in size, and $50 \%$ of particles up to $0.02 \mathrm{~mm}$, and $50 \%$ of particles from $0.02 \mathrm{~mm}$ to $0.075 \mathrm{~mm}$. It was observed that various types of waste act differently on the fatigue of material at all proportions, and also that the maximum elastic modulus was obtained at the proportion of $50 / 50$ for all types of waste material. At that, the best elastic modulus was obtained for the mixture in which the ceramic dust filler was used. The lowest resistance to fatigue was registered for mixtures with the filler consisting of steelworks slag.

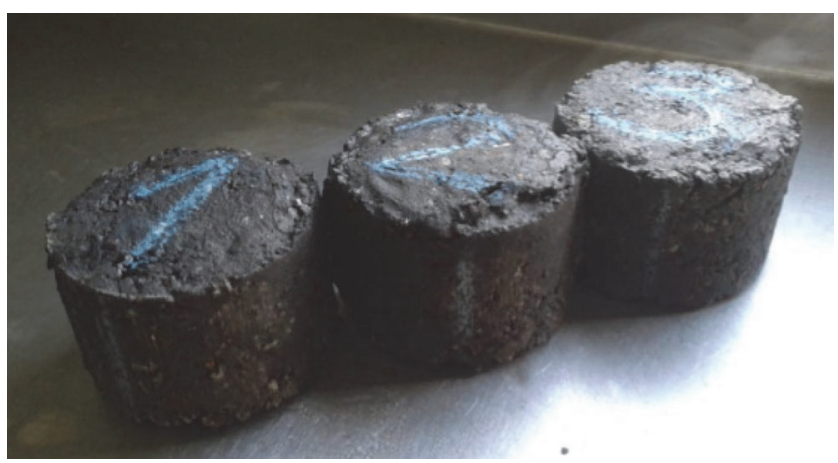

Figure 3 Asphalt samples with $6,2 \%$ of fly ash [37]

In their research, Electricwala et al. [39]) replaced a part of filler with ceramic dust and lime (3-5\%) in the asphalt mixture. Thus the mixture with ceramic dust exhibited a $14.29 \%$ increase in stability compared to the mixture in which the same proportion of lime was used. The latter mixture exhibited a $3.96 \%$ increase in stability compared to traditional filler. Furthermore, the asphalt mixture in which $5 \%$ of filler was replaced with ceramic dust exhibited $10.32 \%$ increase in Marshall's stability compared to the mixture in which lime was used. The authors concluded that the bitumen mixture with ceramic dust is more flexible, and that it will be deformed when subjected to traffic load.

Tapkin [40] studied mechanical properties of mixtures by using the filler made of three types of fly ash (each sample contains different type of fly ash), limestone material, lime and Portland cement. He used six sample types and, for each sample, he tested mechanical properties and elastic modulus. The same author concluded in his paper that the fatigue of material, i.e. the life span of sample in which fly ash was used, is longer compared to the sample in which filler made of limestone material was used. He furthermore concluded that fly ash is especially suitable as filler in mixtures to be incorporated in wearing courses. 
Rahman abd Sobhan [41] studied the possibility of using nonconventional materials as fillers in asphalt mixtures. Nonconventional fillers are non-plastic sand, brick dust and ashes. They compared stabilities obtained on samples with fillers made of stone dust (retained stability) $96.98 \%$, cement $95.39 \%$, non-plastic sand $88.92 \%$, brick dust $87.22 \%$ and ashes $83.59 \%$. Following their investigations, the authors concluded that replacement materials are suitable for use as they meet the limit value of $75 \%$ of retained stability.

Muniandy et al. [42] studied the possibility of using as filler some available industrial waste materials and by-products such as steelworks slag, fly ash, waste from ceramic industry, and limestone waste. The authors concluded that the calcium oxide content is a critical factor in deciding on possible use of these waste materials or by-products as fillers.

Kar et al. [43] analysed three types of mixtures in which cement, stone dust and fly as were used as slag. They established that an optimum proportion of bitumen is almost the same for mixtures in which cement or stone dust were used as filler, while an optimum proportion of bitumen is greater in case of mixtures with fly ash. These authors also established that the retained stability for sample with cement as filler amounts to almost $89 \%$, and almost $87 \%$ percent for sample with stone dust, while for sample with fly as as filler it amounts to a little more than $85 \%$, which is in any case more than the limit value of $75 \%$.

In their paper, Pradhan and Roy [44] study the possibilities of using nonconventional fillers such as brick dust and fly ash in asphalt mixes. Their results show that satisfactory properties according to Marshall have been obtained. Mixtures with fly ash exhibit maximum stability at an optimum bitumen content of $6 \%$. Bituminous mixtures with brick dust exhibit maximum stability at an optimum bitumen content of $7 \%$.

In their research, Sato et al. [45] studied the possibility of using sewage sludge ash in asphalt mixture as replacement for stone dust in proportions of 15, 30, 45 i $100 \%$ by weight. They concluded that sewage sludge can be added as replacement material when used in proportion of up to $45 \%$. Although the residual stability falls when this material is used as filler in asphalt mixture, the total properties of asphalt mixture are improved considerably. The testing also included preparation of fresh concrete with sewage sludge, and the recycling and reuse of this material in load-carrying layers.

In their analysis, Akbulut et al. [46] used sludge resulting from purification of water that is used for cleaning granite during its cutting and polishing. The sludge mainly consists of quartz. The objective of this analysis was to determine possibilities of its use in bitumen mixtures as filler. The sludge passing through the $0.074 \mathrm{~mm}$ sieve was added as filler in the proportion of $0,2,4,6$ and 8 percent. An optimum proportion in the mixture was defined for each mixture using the Marshall procedure. Best results related to mechanical properties and indirect tensile strength were obtained in the mixture in which proportion of this filler amounts to 7.3 percent. The defined optimum proportion of bitumen for mixtures amounted to $5.11,4.76,4.10,4.04$ and $3.83 \%$, which means that the proportion of bitumen falls with and increase in filler content. It was concluded that the mixture with $8 \%$ of sludge as filler attained the greatest density because this filler additionally filled micro-voids in the mixture hence increasing the density and stability of the mixture.

The paper presented by Ahmedzade and Geckil [47] contains tests in which stone aggregate was used for the preparation of samples for stone mixture (Marshall's procedure), while stone dust was used for the filler (control mixture). In the second mixture, stone was used as aggregate, while the black coal dust was used as filler. Asphalt mixtures ( $A C-10$ and $A C-5$ ) were heated to the temperature of $165^{\circ} \mathrm{C}$. The testing revealed that better indirect strength and stability results were obtained in mixtures with coal dust. Stiffness modulus values are higher at lower temperatures $\left(40^{\circ} \mathrm{C}\right)$, but the values coincide with the control mixture values at $20^{\circ} \mathrm{C}$. Furthermore, coal dust improves aggregate and bitumen bonding and increases stiffness and density of the mixture, while reducing sensitivity of asphalt to water. Electrical conductivity of mixture with coal dust is higher compared to the control mixture, which makes this waste material suitable for use in asphalt mixtures for thermoelectric asphalt courses that enable faster melting of snow.

Sargın et al. [48] studied the possibility of using rice husk ashes as filler for asphalt mixes. Four mixtures with 4, 5, 6 and $7 \%$ of filler by weight were designed with an optimum proportion of bitumen. The highest value according to Marshall test (stability) was obtained for the mixture designed with $5 \%$ of filler. An optimum bitumen content for the mix with $4 \%$ of filler amounted to $5.18 \%$, for the mix with $5 \%$ it was $4.73 \%$, for the mix with $6 \%$ the optimum bitumen content was $5 \%$, and for the mix with $7 \%$ the optimum bitumen content amounted to $4.65 \%$. After that, the stone dust was replaced with 25, 50, 75 and 100 percent of rice husk ash. Test results show that the best proportion of rice ash was in the mix with $2.5 \%$ of stone dust and $2.5 \%$ of rice ash (i.e. In the mix where stone dust was replaced with $50 \%$ of rice ash). The Marshall stability reduces with an increase in the rice ash content.

In their research, Karashin and Terzi [49] applied marble dust, i.e. waste formed by cutting, grinding and polishing of marble, as filler in asphalt mixture. Control mix was prepared with stone dust. The Marshall's stiffness test revealed that both mixes exhibit almost the same values and, at that, the mix with marble dust had a higher plastic deformation value. The authors recommend that this waste material be used in the preparation of asphalt mixes for pavements on less-trafficked roadways. In their research conducted in Malaysia, Borhan et al. [50] analysed possibilities for using fly ash from palm oil in asphalt mixes. The objective was to determine an optimum replacement of traditional filler by this waste material in asphalt mixes. The replacement percentage amounted to $0,1,3,5$ and $7 \%$. The results reveal that an optimum ash content is $5 \%$, as it does not affect mechanical and other properties of asphalt mixes. 


\section{Commentary of research}

The analysis of research results reveals that various types of recycled filler can be used as proper replacement of standard fillers. Thus some authors conclude in their studies that the use of waste glass in asphalt mixes increases the stability, reduces deformations and, expectedly, results in lower density of asphalt mixes. It can be concluded from these studies that the use of waste glass does not result in greater difference in properties compared to standard mixes. Other research results show that the use of waste from cement industry in asphalt mixes results in higher stability and lower deformation values. In addition, some authors state that an increase in the cement dust content in mix results in an increase of the optimum proportion of bitumen, and in poorer economic performance of the mix. Further studies show that waste concrete and waste brick particles can be used in asphalt mixes as replacement for traditional filler. It is indicated that waste concrete and waste brick particles can be used up to the grain size of $0.075 \mathrm{~mm}$, that the use of recycled brick dust results in higher stability, and that the use or the recycled concrete dust leads to the fall in stability. Other recycled materials that can be used as fillers are the fly ash, slag, etc. Relevant studies show that different types of filler oscillate as to their influence on the fatigue of materials. Addition of ceramic dust to the mix results in an increase in stability compared to traditional filler, and in creation of a more flexible mix. The use of fly ash increases the life span of asphalt courses compared to limestone-based material, and increases an optimum proportion of bitumen in the mix. Some studies have shown that nonconventional fillers, such as non-plastic sand, brick dust and ashes, are also suitable for use in asphalt mixes as replacement for traditional filler.

One of the most widespread uses of recycled fillers implies the use of waste asphalt in the production of asphalt mixes. In this way, mineral filler from the old asphalt is used, together with other components, in the production of new bitumen mixes. Recycled asphalt is obtained by demolishing, crushing or milling the existing asphalt pavement [51] that contains about $95 \%$ of aggregate grains enveloped with bitumen. Figure 4.a shows available quantities of waste asphalt for individual countries in the period from 2009 to 2014. The following Figure 4.b shows percentage of recycling activity in the same countries (only data for 2014 are available for Great Britain).

Figure 4.a shows that the quantity of recycled asphalt available in observed countres varies from 307,000 tons to 71.4 million tons. Therefore, by far the greatest average four-year quantity of waste asphalt - amounting to 67.92 million tons is registered in the USA. It can also be concluded from Figure 4.b that the greatest quantity of waste asphalt is used in the USA and that it amounts to $90 \%$ in the production of hot and warm asphalt mixes. If it is assumed that an average content of filler in bitumen mixes amounts to $5 \%$, it can be concluded that some 3.396 million tons of filler is used in the USA only from waste asphalt. In the Republic of Croatia, this trend is in the initial stage, as witnessed by a small available quantity of waste asphalt (170.000 tons) registered in 2014 [3] out of which only $24 \%$ is used in the production of hot and warm asphalt mixes.
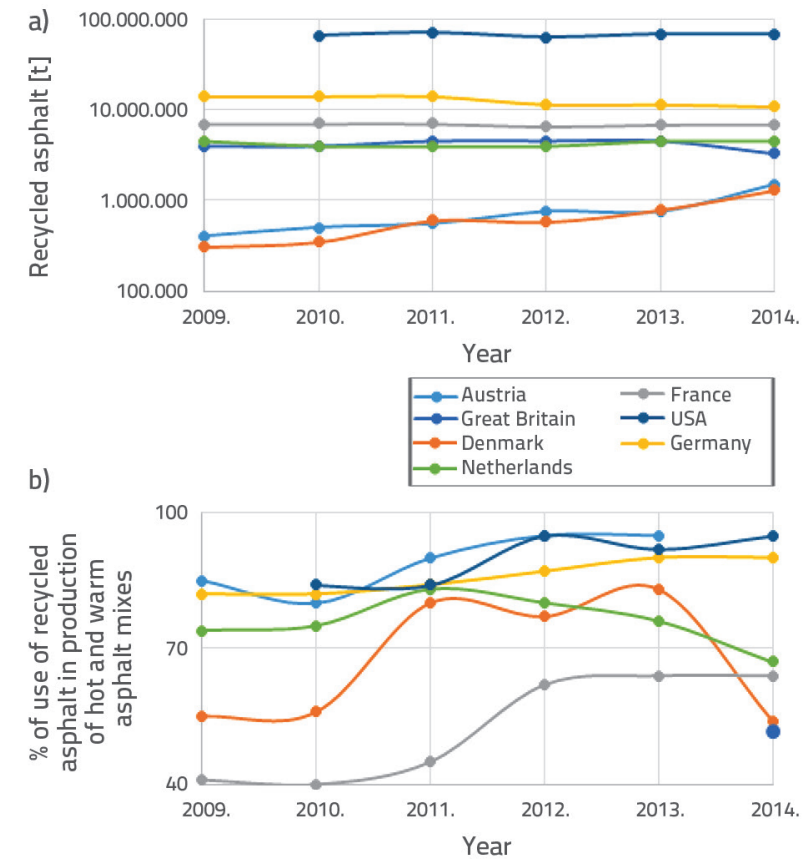

Figure 4. Recycled asphalt and its use in individual countries: a) available quantities of recycled asphalt [52-55, 3]; b) \% of use of recycled asphalt in production of hot and warm asphalt mixes [52-55, 3]

\section{Conclusion}

Current tendencies aimed at reducing negative environmental impacts and encouraging sustainable construction have resulted in ever increasing demands for the use of waste materials in the production of asphalt mixes. The basic objective of this research was to analyse research conducted so far with regard to the use of various waste materials as replacement for traditional fillers in asphalt mixes. The analysis of individual filler replacement in asphalt mixes was selected due high influence of filler on the quality of asphalt. According to research made by many authors, it can be concluded that waste glass, cement industry waste materials, concrete, bricks, ceramics, fly ash and other raw materials can be used as replacement for standard filler in bituminous mixes. It can also be concluded that the use of various non-conventional fillers should additionally be studied through construction of trial sections in order to enable better analysis of behaviour of such asphalt layers in actual use. The use of various waste fillers in the production of asphalt mixes has lead to the fall in the price of mixes, and in a more acceptable influence of asphalt industry on natural environment. 


\section{REFERENCES}

[2] Barišić, I., Zagvozda, M., Dimter, S.: Usage of Alternative, environmentally Acceptable Materials-Experience from Eastern Croatia, 2nd International Conference on Innovative Materials, Structures-and Technologies, IOP Conf. Series: Materials Science and Engineering 96, 2015.

[3] Direktiva 2008/98/EC on Waste (Waste Framework Directive), online: ec. europa. Eu / environment /waste / framework/

[4] Asphalt.in.figures.2014,.EAPA,.online:.http://www.eapa.org/ userfiles/2/Asphalt\%20in \%20Figures/2014/AlF_2014_v10.pdf.

[5] McDonald, M.R.: Recycled materials relational database: Design and implementation aspects, Department of Civil and Environmental Engineering, College of Engineering, University of South Florida, 2004.

[6] Dimter, S., Androjić, l.: Primjena recikliranog asfalta u proizvodnji asfaltnih mješavina, EU fondovi i projekti prometne infrastrukture Zagreb (ur. Lakušić, S.), Građevinski fakultet Sveučilišta u Zagrebu, Zavod za prometnice, 2014., pp. 237-268.

[7] Androjić, I., Dimter, S.: Prilog istraživanju mješavina s recikliranim agregatom, GRAĐEVINAR, 65 (2013) 1, pp. 37-43.

[8] Androjić, l., Kaluđer, G., Komljen, M.: Primjena recikliranog asfalta u bitumeniziranom nosivom sloju, GRAĐEVINAR, 64 (2012) 5, pp. 395-401.

[9] Hoon-Moon, K., Cannone-Falchetto, A., Marasteanu, M., Turos, M.: Using Recycled Asphalt Materials as an Alternative Material Source in Asphalt Pavement, KSCE Journal of Civil Engineering, 18 (2014) 1, pp. 149-159.

[10] Jitendra, K., Thakur, J.H.: Development of Recycled Asphalt Pavement (RAP) Bases Treated for Roadway Applications, Transp. Infrast. Geotech., (2015) 2, pp. 68-86.

[11] Hassani, A., Ganjidoust, H., Maghanaki, A.A.: Use of plastic waste (poly-ethylene terephthalate) in asphalt concrete mixture as aggregate replacement, Waste Manag. RES., 23 (2005) 4, pp. 322-327.

[12] Jafar, J.J.: Utilisation of waste plastic in bituminous mix for improved performance of roads, KSCE Journal of Civil Engineering, 20 (2016) 1, pp. 243-249.

[13] Khan, S.T., Sharma, S.D.K., Sharma, B,M.: Performance evaluation of waste plastic polymer modified bituminius concrete mixes, Journal of Scientific\&Industrial Research, 68 (2009), pp. 975-979.

[14] Su N., Chen, J.S.: Engineering properties of asphalt concrete made with recycled glass, Resour Conserv Recycl, 35 (2002) 4, pp. 259274.

[15] Jasim, A.A.: By using waste glass as secondary aggregates in asphalt mixtures, International Journal of Advanced Research, 2 (2014) 1, pp. 41-46.

[16] Celik, O.: Influence of fly ash on the Properties of Asphalt, Petroleum Science And Technology, 13 (2008), pp. 1571-1582, https://doi.org/10.1080/10916460701287474

[17] Kar, D., Panda, M., Giri, J.P.: Influence of fly ash as filler in bituminous mixes, ARPN Journal of Engineering and Applied Sciences, 9 (2014) 6, pp. 895-900.

[18] Roberts, L.F., Kandhal, S.P., Brown, R.E., Lee, Y.D., Kennedy, W.T.: Hot Mix Asphalt materials, mixture design, and construction. NAPA Education Foundation, Lanham Maryland, 1996.

[19] Razrada tehničkih svojstava i zahtjeva za građevne proizvode za proizvodnju asfaltnih mješavina i za asfaltne slojeve kolnika, Hrvatske ceste d.o.o., Zagreb, lipanj 2013. (ispravljena verzija).
[20] Ramljak, Z., Strineka, A., Šafran, K.: Ovisnost vlačne čvrstoće asfaltnog uzorka o njegovom sastavu, GRAĐEVINAR, 57 (2005) 3, pp. 141-150.

[21] Santos-Bardini, V.S., Fernandez-Junior, J.L., Gutierrez-Klinsky, L.M.: Influence of mineral filler on volumetric properties of hot mix asphalt, International journal of pavements conference, Sao Paolo, 2013.

[22] Hriberski-Leskovar, A.: Staklena ambalaža i okoliš, 2005, online: www.ambalaza.hr

[23] Eurostat (2013) Packaging waste statistics http://epp.eurostat. ec.europa.eu/statistics_explained/index.php/Packaging_waste_ statistics. (pristup 06.08.2014).

[24] Report for 2012 (2014) Agencija za zaštitu okoliša, online: www. azo.hr/Otpad01.

[25] Androjić, I., Dimter, S.: Properties of hot mix asphalt with substitued waste glass, Materials and Structures, 1 (2016) 1, pp. 249-259.

[26] Hassan, H.J., Mays, F.A., Israa, Y.J.: The Effect of Using Glass Powder Filler on Hot Asphalt Concrete Mixtures Properties, Eng. \& Tsch. Journal, 29 (2011) 1, pp. 44-57.

[27] Jony, H., Al-Rubaie, M., Jahad, I.: The effect of using glass powder ller on hot asphalt concrete mixtures properties. Eng. and Technology Journal, 29 (2011) 1, pp. 58-67.

[28] Shaopeng, W., Wenfeng, Y., Yongjie, X.: Preparation and Properties of Glass-asphalt Concrete, Key Laboratory for Silicate Materials Science and Engineering of Ministry of Education, Wuhan University of Technology, 2003, Wuhan.

[29] Pereira, V., Morais, C., Silva, E., Tavares: Residue Flat Glass: Recycling In the Form of Filler in Asphalt Mixtures, XXII International Congress on Glass, Bahia, Brazil, pp. 124-129, 2010.

[30] Utjecaj cementne industrije na održivi razvoj i zbrinjavanje štetnih otpada, Zaštita okoliša u Hrvatskoj u procesu pristupanja EU, online: www.hdki.hr/_news/33337/Plakat \%20-\%20krolo2pdf.

[31] Hassan, Y.A., Ayman, M.O., Afaf, A.M.: Effect of using waste cement dust as a mineral filler on the mechanical properties of hot mix asphalt, ASS. Univ. Bull. Environ. Res., 9 (2006) 1, pp. 5160.

[32] Khaled, Z.R., Ahmed, M.A.: Utilization of white cement bypass dust as filler in asphalt concrete mixtures, Canadian Journal of Civil Engineering, 36 (2009), pp. 191-195, https://doi.org/10.1139/ L08-124

[33] Taha, R., Al-Rawas, A., Al-Harthy, A.S.: Use of Cement Bypass Dust as Filler in Asphalt Concrete Mixtures, Journal of Materials in Civil Engineering, 14 (2002) 4, pp. 338-343.

[34] Sutradhar, D., Mintu, M., Golam, J.C., Mohd, A.S.: Effect of Using Waste Material as Filler in Bituminous Mix Design, American Journal of Civil Engineering, 3 (2015) 3, pp. 88-94.

[35] Taherkhani, H., Golzari, A.: An investigation on the viability of using recycled concrete and steel slag powder as filler in asphalt concrete, International Journal of Current Life Sciences, 4 (2014) 2, pp. 709-716.

[36] Chen, M., Lin, J., Wu, S.: Potential of recycled fine aggregates powder as filler in asphalt mixture, Construction and Building Materials, 25 (2011), pp. 3909-3914, https://doi.org/10.1016/j. conbuildmat.2011.04.022

[37] Androjić, I., Kaluder, G., Komljen, M.: Usage of fly ash in Hot Asphalt Mixes, XXVIII International Baltic Road Conferences, 2013. 
[38] Muniandy, R., Aburkaba, E.: The effect of type and particle size of industrial wastes filler on Indirect Tensile Stiffness and Fatigue performance of Stone Mastic Asphalt Mixtures, Australian Journal of Basic and Applied Sciences, 5 (2011) 11, pp. 297-308.

[39] Electricwala, F., Sadanand, S., Ankit, J., Rakesh, K.: Use of Ceramic Waste as Filler in Semi-Dense Bituminous Concrete, American Journal of Civil Engineering and Architecture, 2 (2014) 3, pp. 102106.

[40] Tapkin, T.: Mechanical evaluation of asphalt-aggregate mixtures prepared with fly ash as a filler replacement, Canadian Journal of Civil Engineering, 35 (2008) 1, pp. 27-40.

[41] Rahman, M.N., Sobhan, M. A.: Use of Non-Conventional Fillers on Asphalt-Concrete Mixture, International Journal of Innovation and Applied Studies, 3 (2013) 4, pp. 1101-1109.

[42] Muniandy, R., Aburkaba, E.E., Hamid, H.B., Robiah, B.T.Y.: An initial investigation of the use of local industrial wastes and by-products as mineral fillers in stone mastic asphalt pavements, ARPN Journal of Engineering and Applied Sciences, 4 (2009) 3, pp. 5463.

[43] Kar, D., Panda, M., Giri, J.P.: Influence of fly-ash as a filler in bituminous mixes, ARPN Journal of Engineering and Applied Sciences, 9 (2014) 6, pp. 895-900.

[44] Pradhan, S., Roy, P.: Efffect of fillers on Bituminous Paving Mixes, NIT, Rourkela, 2008

[45] Sato, Y., Oyamada, T., Hanehara, S.: Applicability of sewage sludge ash (SSA) for paving materials: A study on using SSA as filler for asphalt mixture and base course material, Third International Conference on Sustainable Construction Materials and Technologies, 18-21 August 2013, Kyoto Research Park, Kyoto, Japan
[46] Akbulut, H., Gürer, C., Çetin, S., Elmacı, A.: Investigation of using granite sludge as filler in bituminous hot mixtures, Construction and Building Materials, 36 (2012), pp. 430-436, https://doi. org/10.1016/j.conbuildmat.2012.04.069

[47] Ahmedzade, P., Geckil, T.: Influence of carbon black on the mechanical and electrical properties of asphalt mixtures, Indian Journal of Engineering \& Materials Sciences, 14 (2007), pp. 358364.

[48] Sargın, S., Saltan, M., Morova, N., Serin, S., Terzi, S.: Evaluation of rice husk ash as filler in hot mix asphalt concrete, Construction and Building Materials, 48 (2013), pp. 390-397, https://doi. org/10.1016/j.conbuildmat.2013.06.029

[49] Karashin, M., Terzi, S.: Evolution of marble dust in mixture of asphaltic concrete, Construction Building Materials, 21 (2007) 3, pp. 616-620.

[50] Borhan, M.N., Ismail, A., Rahmat, R.A.: Evaluation of Palm Oil Fuel Ash (POFA) on Asphalt Mixtures, Australian Journal of Basic and Applied Sciences, 4 (2010) 10, pp. 5456-5463.

[51] Schwabe, Ž.: Recikliranje asfaltnih kolničkih konstrukcija, Gospodarenje prometnom infrastrukturom (ur. Lakusic, S.), Dani prometnica 2009, Zagreb, rujan 2009. pp. 189-239.

[52] Asphalt.in.figures.2013,.EAPA,.online:.http://C:/Users/lvica/ Downloads/EAPA++Asphalt+in+Figures+2013.pdf.

[53] Asphalt.in.figures.2012,.EAPA,.online:.http://www.eapa.org/ userfiles/2/Asphalt \%20in \%20Figures/Asphalt \%20in \%20figures $\% 2022-11-2013$.pdf.

[54] Asphalt.in.figures.2011,.EAPA,.online:.http://www.eapa.org/ userfiles/2/Asphalt \%20in \%20Figures/Asphalt \%20in \%20figures $\%$ 2029-11-2012.pdf.

[55] Asphalt.in.figures.2010,.EAPA,.online:.http://www.eapa.org/usr img/Asphalt \%20in \%20figures \%20Version \%2022-12-2011.pdf. 